TITLE:

\title{
A strontium isotope analysis on the relationship between ritual tooth ablation and migration among the Jomon people in Japan
}

\section{$\operatorname{AUTHOR}(S)$ :}

Kusaka, Soichiro; Ando, Atsushi; Nakano, Takanori; Yumoto, Takakazu; Ishimaru, Eriko; Yoneda, Minoru; Hyodo, Fujio; Katayama, Kazumichi

\section{CITATION:}

Kusaka, Soichiro ...[et al]. A strontium isotope analysis on the relationship between ritual tooth ablation and migration among the Jomon people in Japan. Journal of Archaeological Science 2009, 36(10): 2289-2297

\section{ISSUE DATE:}

2009-10

URL:

http://hdl.handle.net/2433/85227

\section{RIGHT:}

c 2009 Elsevier Ltd. All rights reserved.; This is not the published version. Please cite only the published version.; この論文は出版社版でありませ ん。引用の際には出版社版をご確認ご利用ください。 
Journal of Archaeological Science 36 (2009) 2289-2297

Article title:

A strontium isotope analysis on the relationship between ritual tooth ablation and migration among the Jomon people in Japan

Authors:

Soichiro Kusaka $^{\mathrm{a}^{*}}$, Atsushi Ando ${ }^{\mathrm{b}, \mathrm{c}}$, Takanori Nakano ${ }^{\mathrm{b}}$, Takakazu Yumoto ${ }^{\mathrm{b}}$, Eriko Ishimaru $^{\mathrm{b}}$, Minoru Yoneda ${ }^{\mathrm{d}}$, Fujio Hyodo ${ }^{\mathrm{e}}$, Kazumichi Katayama ${ }^{\mathrm{a}}$

Affiliations and addresses:

${ }^{a}$ Department of Zoology, Graduate School of Science, Kyoto University, Kyoto 606-8502, Japan

${ }^{\mathrm{b}}$ Research Institute for Humanity and Nature, Kyoto 603-8047, Japan

${ }^{c}$ BK21 Coastal Environmental System School, Division of Earth Environmental System, Pusan National University, Busan 609-735, Korea

dDepartment of Integrated Biosciences, Graduate School of Frontier Sciences, The University of Tokyo, Chiba 277-8561, Japan

${ }^{\mathrm{e}}$ Research Core for Interdisciplinary Sciences, Okayama University, Okayama

700-8530, Japan

*Corresponding author.

Tel.: +81-75-753-4094; Fax: +81-75-753-4083

E-mail: kusaka@anthro.zool.kyoto-u.ac.jp 
Journal of Archaeological Science 36 (2009) 2289-2297

\section{Abstract}

Distinct patterns can be discerned in the extensive ritual tooth ablation found among the human skeletal remains of the Late-Final Jomon period (ca. 3200-2800 cal BP) in Japan. Based on comparative observations of sex and grave patterns in the skeletal remains, two major patterns in ritual tooth ablation, termed type $4 \mathrm{I}$ and type $2 \mathrm{C}$, have been assigned to locals and immigrants, respectively. In order to test this hypothesis, strontium (Sr) isotope $\left({ }^{87} \mathrm{Sr} /{ }^{86} \mathrm{Sr}\right)$ analyses were performed on human skeletal remains from the Yoshigo shell mound in Aichi Prefecture, central Japan. Plants in the surrounding area were also examined to illustrate the geographic ${ }^{87} \mathrm{Sr} /{ }^{86} \mathrm{Sr}$ distribution. The $\mathrm{Sr}$ isotopic variation in human tooth enamel $\left({ }^{87} \mathrm{Sr} /{ }^{86} \mathrm{Sr}=0.70868-0.71028\right)$ was greater than that in human bones $\left({ }^{87} \mathrm{Sr} /{ }^{86} \mathrm{Sr}=0.70871-0.70943\right)$. Individuals with higher $\mathrm{Sr}$ isotope ratios in their tooth enamel than seawater Sr values of 0.7092 can be identified as immigrants ( $36 \%$ of population). The presence of these isotopically identified immigrants among both type $2 \mathrm{C}$ and type $4 \mathrm{I}$ individuals does not support the previous hypothesis. The intra-population ${ }^{87} \mathrm{Sr} /{ }^{86} \mathrm{Sr}$ distribution of tooth enamel of type $2 \mathrm{C}$ individuals showed a significantly higher mean ratio than that of type $4 \mathrm{I}$ individuals, suggesting a higher proportion of immigrants among the former.

Keywords: Jomon period; hunter-gatherers; strontium isotopes; mobility; ritual tooth ablation 


\section{Introduction}

The period of Jomon culture in the Japanese Archipelago lasted from 13000 to 2300 years BP. The Jomon people were hunter-gatherers who are well known for their cord-marked pottery. A brief description of the Jomon culture is presented in Table 1 (for details, see Habu, 2004; Harunari, 1986; Imamura, 1996). The Jomon people in general led a sedentary life, effectively exploiting marine and/or terrestrial resources. As their numbers declined during the Late-Final Jomon period (ca. 4000-2300 BP), ritual practices and artifacts developed and changed (Imamura, 1996).

A widely debated question in Japanese archaeology concerns ritual tooth ablation among the Jomon people, which was characterized by a variety of forms and widely practiced during the Late-Final Jomon period (e.g., Watanabe, 1966; Harunari, 1979, 1986). Patterns in tooth ablation provide an invaluable source of information on the social structure of the Jomon people. Several interpretations have been proposed, such as a coming-of-age ceremony (Funahashi, 2003; Harunari, 1979; Hasebe, 1919), mourning for a deceased family member (Funahashi, 2003; Harunari, 1979), representation of descent group (Yamada, 2008), and representation of moiety group (Tanaka, 1998).

The most influential interpretation of variation in ritual tooth ablation is that proposed by Harunari (1979). Comparisons of sex and grave patterns of Jomon skeletal remains have led this author to hypothesize that ritual tooth ablation was performed at a coming-of-age ceremony and at marriage, and that different types of ablation can distinguish locals from immigrants. The proposed five types of ritual tooth ablation and their interpretations are (Fig. 1): (1) type 0 individuals, with two maxillary incisors removed, representing the coming-of-age tooth ablation; (2) type 4I individuals, with additional four mandibular incisors removed, whose burial with personal offerings (such as hip accessories and earrings) led Harunari (1979) to conclude that they were locals of high prestige; (3) type $2 \mathrm{C}$ individuals, who lacked all canines and who were immigrants married to type 4I individuals; (4) type 4I2C, with all canines and four mandibular incisors removed; and (5) type 2C2I, with all canines and two mandibular central incisors removed, which characterize people married more than once. Harunari (1979) extended this interpretation to propose the ambilocal system for the rule of residence after marriage in Jomon society, because type $2 \mathrm{C}$ individuals, who were immigrants, include both males and females.

Harunari's (1979) hypothesis has been assessed through the methods of physical anthropology. A cranial nonmetric trait study of migration patterns (Mouri and Oku, 1998) supported this hypothesis. In contrast, Funahashi's (2003) comparison of the age of human skeletons and the timing of ritual tooth ablation showed that ablation also occurred before marriage and childbirth. It is not clear whether the hypothesis is valid. Thus, Harunari's (1979) hypothesis needs to be tested by independent lines of evidence.

The purpose of the present study was to provide a strontium ( $\mathrm{Sr}$ ) isotopic $\left({ }^{87} \mathrm{Sr} /{ }^{86} \mathrm{Sr}\right.$ ) test for Harunari's (1979) hypothesis that tooth ablation types and migration were closely related during the Jomon period. Strontium isotopes have been widely used in archaeological science as tracers of prehistoric residential mobility (e.g., Bentley et al., 2002, 2005, 2007; Ezzo et al., 1997; Haak et al., 2008; Knudson and Buikstra, 2007; Montgomery et al., 2007; Price et al., 2002). Application of this method to reveal mobility among hunter-gatherers is still developing (Haverkort et al., 2008; Tafuri et al., 2006). The rationale is that $\mathrm{Sr}$ isotope composition in plants and animals faithfully reflects that of their geological background, because biologically available $\mathrm{Sr}$ 
originating from rocks and soil is incorporated into biosynthetic processes with no isotope fractionation along a food chain (Blum et al., 2000). Thus, if human migration did occur between geologically contrasting residential areas, the $\mathrm{Sr}$ isotopic signatures in the tooth enamel of immigrants, an excellent archive of $\mathrm{Sr}$ in their childhood, would differ from those in other adult human bones as well as those in soil, plants, and other regional animals (Bentley, 2006).

This study is the first to apply Sr isotope analysis to Jomon skeletal remains. In addition to detailed ${ }^{87} \mathrm{Sr} /{ }^{86} \mathrm{Sr}$ measurements of human skeletal remains, extensive mapping of Sr isotopes in plants was completed to estimate the geographical origin of immigrants (e.g., Hodell et al., 2004; Wright, 2005). We then examined the relationship between $\mathrm{Sr}$ isotope-based immigrants and tooth ablation types in light of tests on Harunari's (1979) hypothesis.

\section{Materials and Methods}

The Yoshigo shell mound is located on the northern coast of the Atsumi Peninsula, Aichi Prefecture (Fig. 2). The mound was excavated in 1922 (Kiyono, 1969). About 300 human skeletons were recovered. This collection of skeletal remains was one of the main types of material to provide the basis for research by Harunari (1979). The site is dated as extending from the later part of the Late Jomon period to the Final Jomon period (ca. 3500-2300 BP) based on the chronology of pottery types (Yamanouchi, 1952). Essentially consistent ages (ca. 3200-2800 cal BP) have been newly established by radiocarbon dating of human bone collagen (see Appendix 1).

For this study, 39 third molars and 37 rib samples were selected from individuals with definite ritual tooth ablation in the collection of the Laboratory of Physical Anthropology, Department of Zoology, Graduate School of Science, Kyoto University (Appendix 2). We assumed that tooth enamel in the third molar retains Sr acquired from the diet during childhood (9-13 years old [Hillson, 1996]). Bone retains averaged $\mathrm{Sr}$ isotope ratios for about the previous 10 years of one's lifetime, because the turnover time of bone is about 10 years (Stenhouse and Baxter, 1979). This dietary signature in bone, however, cannot be completely retained because of the effect of diagenetic alteration, as discussed later. Plant samples (tree leaves, e.g., Chinese hackberry) were collected from 40 locations in the surrounding area of Mikawa Bay and along the Pacific coast (Appendix 3).

Human tooth and bone samples were ultrasonically cleaned in ultrapure water and then dried. Human tooth samples were embedded in resin and cut longitudinally with a Minitom diamond cutter (Marumoto Struers K.K.). A dental drill equipped with a diamond burr was used to abrade tooth enamel and bone samples. After abrading the surface area to remove soil-derived substances, enamel samples $(5 \mathrm{mg})$ were collected. Human bone samples $(5 \mathrm{mg}$ ) were also obtained from the compact bone of ribs.

Strontium isotope analysis was performed at the Research Institute for Humanity and Nature (RIHN), including the pretreatment steps in a clean laboratory. Buffered acetic acid solution $(0.1 \mathrm{M}, \mathrm{pH}=4.5,1 \mathrm{ml})$ was used to eliminate diagenetic contaminants from enamel and bone samples (Hoppe et al., 2003; Sillen, 1986; Trickett et al., 2003). The samples were agitated for 10 minutes in the acetic acid solution, and after centrifugation, the solution was discarded. After performing this procedure twice, a further 10-minute leach solution was obtained as supernatant. Each plant sample $(0.5 \mathrm{~g}$; ashed in a muffle furnace at $650^{\circ} \mathrm{C}$ for 24 hours) was placed in a centrifuge tube, to which ultrapure water $(10 \mathrm{ml})$ was added, and left overnight. After centrifugation, 
sample solution was obtained as supernatant.

All solution samples were dried down in Teflon ${ }^{\circledR}$ vials on a hotplate. Then $\mathrm{HNO}_{3}$ (14M) was added and the vials were placed on a hotplate at $200^{\circ} \mathrm{C}$ to decompose organic matter. Samples were dissolved in $\mathrm{HCl}(2 \mathrm{M})$, and $\mathrm{Sr}$ was separated chromatographically by using cation exchange resin (DOWEX, $50 \times 8,200-400 \mathrm{mesh}$ ). Strontium isotope ratios were measured on degassed tungsten filament with a TRITON thermal ionization mass spectrometer (Thermo Fisher Scientific K.K.). Normalization of sample ${ }^{87} \mathrm{Sr} /{ }^{86} \mathrm{Sr}$ data was based on the difference between the within-run average of NIST SRM 987 and its recommended value, for which we accepted 0.710250 (Faure and Mensing, 2005). Internal precision based on 100 times of ion counting was \pm $0.000003-0.000010$ (=1 standard error). External precision determined by repeated measurements $(n=104)$ of NIST SRM 987 was $\pm 0.000007(=1$ standard deviation [s.d.]) with the mean of 0.710256 throughout all measurements over 6 months. All ${ }^{87} \mathrm{Sr} /{ }^{86} \mathrm{Sr}$ data are listed in Appendices 2 and 3.

\section{Results}

\subsection{Strontium isotopes in skeletal remains from the Yoshigo site}

Strontium isotope ratios in human tooth enamel were $0.70925 \pm 0.00036$ (mean \pm 1 s.d.) with a range of $0.70868-0.71028$. Human bone had ${ }^{87} \mathrm{Sr} /{ }^{86} \mathrm{Sr}$ ratios of $0.70895 \pm$ 0.00018 with a range of $0.70871-0.70943$. The mean value of tooth enamel was higher than that of bone, and the standard deviation of tooth enamel was larger than that of bone. The minimum ${ }^{87} \mathrm{Sr} /{ }^{86} \mathrm{Sr}$ ratios were almost the same for both tooth enamel and bone, but the maximum ${ }^{87} \mathrm{Sr} /{ }^{86} \mathrm{Sr}$ ratio of human tooth enamel was higher than that of bone.

It should be noted that $\mathrm{Sr}$ isotopic records in bone hydroxyapatite are generally susceptible to diagenetic alteration because of the relatively porous crystal structure of bone hydroxyapatite (Hoppe et al., 2003; Sillen, 1986; Trickett et al., 2003).

Specifically, compact bone of ribs that we studied would be more porous than the compact bone of long bones. Diagenesis would narrow the primary ${ }^{87} \mathrm{Sr} /{ }^{86} \mathrm{Sr}$ variation in bone samples, and lower the ${ }^{87} \mathrm{Sr} /{ }^{86} \mathrm{Sr}$ ratios. The ${ }^{87} \mathrm{Sr} /{ }^{86} \mathrm{Sr}$ ratios in bones could be equilibrated with those of the ground water (Bentley, 2006). Two of the sources of $\mathrm{Sr}$ in ground water are weathered minerals and soil, which have lower ${ }^{87} \mathrm{Sr} /{ }^{86} \mathrm{Sr}$ ratios $(<0.709)$ that would be expected from the local geology of the site. Another source of $\mathrm{Sr}$ is seawater, which has a ratio of 0.7092 because in coastal areas the ${ }^{87} \mathrm{Sr} /{ }^{86} \mathrm{Sr}$ ratios can be dominated by sea-spray or rainwater derived from evaporated seawater (Bentley, 2006, Whipkey et al., 2000). Furthermore, modern precipitation in Japan shows mean ${ }^{87} \mathrm{Sr} /{ }^{86} \mathrm{Sr}$ ratios of 0.7089 and ranges of $0.7065-0.7100$ (Nakano et al., 2006). The mixing of those sources constitutes diagenetic Sr. Diagenesis would result in bone ${ }^{87} \mathrm{Sr} /{ }^{86} \mathrm{Sr}$ ratios of $0.7086-0.7092$ in most individuals. Thus, we assumed that bone ${ }^{87} \mathrm{Sr} /{ }^{86} \mathrm{Sr}$ ratios are characterized by diagenesis as well as the diet of the Yoshigo population. Some exceptional individuals had higher bone $\mathrm{Sr}$ isotope ratios, with values greater than 0.7092 , because they had died several years after immigration but before their bones could fully match local Sr isotope ratios.

\subsection{Geographic ${ }^{87} \mathrm{Sr} /{ }^{86} \mathrm{Sr}$ distribution of plants}

Fig. 3A shows the geographic ${ }^{87} \mathrm{Sr} /{ }^{86} \mathrm{Sr}$ distribution of plants in the surrounding area of the Yoshigo site. A wide range of ${ }^{87} \mathrm{Sr} /{ }^{86} \mathrm{Sr}$ variation can be recognized, with high ${ }^{87} \mathrm{Sr} /{ }^{86} \mathrm{Sr}$ ratios (up to 0.7142 ) dominating the north of the study area, and low ${ }^{87} \mathrm{Sr} /{ }^{86} \mathrm{Sr}$ 
ratios (as low as 0.7070 ) occurring in the east of the study area (Appendix 3). Strontium isotope ratios in plants in the Atsumi Peninsula represent the intermediate values of these two end members.

The observed ${ }^{87} \mathrm{Sr} /{ }^{86} \mathrm{Sr}$ variation in plants correlates very well with the surface geology (Fig. 3B). In the north of the study area, where ${ }^{87} \mathrm{Sr} /{ }^{86} \mathrm{Sr}$ ratios in plants are distinctively high, granitic rocks of the Ryoke Belt are extensively exposed. In contrast, low ${ }^{87} \mathrm{Sr} /{ }^{86} \mathrm{Sr}$ ratios in the east of the study area overlap with the distribution of the limestone and chert of the Chichibu Belt. Similarly, relatively low ${ }^{87} \mathrm{Sr} /{ }^{86} \mathrm{Sr}$ ratios in the Atsumi Peninsula appear to correspond with the distribution of the Chichibu Belt. It is noteworthy that the observed relationship between ${ }^{87} \mathrm{Sr} /{ }^{86} \mathrm{Sr}$ ratios and rock type is predictable in light of the empirically known ${ }^{87} \mathrm{Sr} /{ }^{86} \mathrm{Sr}$ range in the earth's lithosphere (i.e., ${ }^{87} \mathrm{Sr} /{ }^{86} \mathrm{Sr}>0.712$ for granitic continental crust; ${ }^{87} \mathrm{Sr} /{ }^{86} \mathrm{Sr}=0.707-0.709$ for minerals of marine origin, e.g., Bentley, 2006).

Sea-spray effect was observed in the ${ }^{87} \mathrm{Sr} /{ }^{86} \mathrm{Sr}$ ratios of coastal areas (Fig. 3A). Even in the north of the study area, plants from coastal areas showed lower ${ }^{87} \mathrm{Sr} /{ }^{86} \mathrm{Sr}$ values than those from inland areas. The lowest ${ }^{87} \mathrm{Sr} /{ }^{86} \mathrm{Sr}$ ratios were present in the inland region of the east of the study area. The Atsumi Peninsula is likely to be affected by sea-spray; therefore, most of the plant ${ }^{87} \mathrm{Sr} /{ }^{86} \mathrm{Sr}$ ratios equilibrate toward seawater ratios and exhibit small variation.

We subdivided the study area into four regions based on the location of the Yoshigo shell mound, geographic ${ }^{87} \mathrm{Sr} /{ }^{86} \mathrm{Sr}$ distribution in plants, and geology (Fig. 3A). This subdivision enabled us to estimate the geographical origin of immigrants. First the "Yoshigo area" was defined as being within a radius of $10 \mathrm{~km}$ of the Yoshigo shell mound $\left({ }^{87} \mathrm{Sr} /{ }^{86} \mathrm{Sr}=0.70907 \pm 0.00037\right.$ [mean \pm 1 s.d.] $)$, because the foraging radius of hunter-gatherers is generally within $10 \mathrm{~km}$ from a settlement, although this radius varies (Binford, 2001). Next, the "north area" was defined as the northern coastal area of Mikawa Bay (to the west of the Toyo River), comprising the Ryoke Belt $\left({ }^{87} \mathrm{Sr} /{ }^{86} \mathrm{Sr}=\right.$ $0.71140 \pm 0.00192)$. The "east area" lies to the east of the Yoshigo area and to the south of the Toyo River, and consists mainly of the Chichibu Belt $\left({ }^{87} \mathrm{Sr} /{ }^{86} \mathrm{Sr}=0.70859 \pm\right.$ 0.00090). Finally, we defined the remainder of the study area, to the point of the Atsumi Peninsula, as the "west area" $\left({ }^{87} \mathrm{Sr} /{ }^{86} \mathrm{Sr}=0.70910 \pm 0.00019\right)$.

The mean plant ${ }^{87} \mathrm{Sr} /{ }^{86} \mathrm{Sr}$ ratios in the four regions differ from each other (one-way analysis of variance, $P<0.0001$ ). Student's $t$-test (Table 2) shows that the mean ${ }^{87} \mathrm{Sr} /{ }^{86} \mathrm{Sr}$ ratio in plants in the north area is significantly higher than that in the Yoshigo area, east area, or west area $(P<0.0011)$. This result suggests that $\mathrm{Sr}$ isotope analysis of the Yoshigo population can be used to identify immigrants from the north area.

It should be noted that agricultural fertilizers could have affected plant ${ }^{87} \mathrm{Sr} /{ }^{86} \mathrm{Sr}$ ratios (Bentley, 2006). On the Atsumi Peninsula, Paleozoic limestone and chert have nonradiogenic ${ }^{87} \mathrm{Sr} /{ }^{86} \mathrm{Sr}$ ratios of $<0.709$. Theoretically, plant ${ }^{87} \mathrm{Sr} /{ }^{86} \mathrm{Sr}$ ratios comprising a two-component mix of weathered minerals and a marine input would be between 0.7080 and 0.7092. Some plant Sr isotope values in the Atsumi Peninsula, however, show values above 0.7092 . These values may result from agricultural fertilizers with relatively radiogenic $\mathrm{Sr}$ isotope ratios. Because we collected only plants growing naturally on flat land or hillside terraces, we expected minimal levels of $\mathrm{Sr}$ sourced from agricultural fertilizers in these samples. Despite such artificial sources of $\mathrm{Sr}$, local geology still has a significant effect on ${ }^{87} \mathrm{Sr} /{ }^{86} \mathrm{Sr}$ ratios in the regions. Therefore, plant ${ }^{87} \mathrm{Sr} /{ }^{86} \mathrm{Sr}$ ratios show clear regional differences associated with local geology. 


\subsection{Identifying immigrants in the Yoshigo population}

By determining the "local" ${ }^{87} \mathrm{Sr} /{ }^{86} \mathrm{Sr}$ range for this dataset, immigrants can be distinguished from locals. To identify biologically available $\mathrm{Sr}$ in the Yoshigo population, assessing two major sources of $\mathrm{Sr}$, marine and terrestrial, was important. According to the carbon and nitrogen isotope analysis on the Yoshigo skeletal remains, these people consumed considerable amounts of marine food, although the proportion in the diet differed among individuals (Kusaka et al., 2008). In Appendix 1, the three radiocarbon dates also show a range in marine food consumption of 20-88\%. A high proportion of seafood consumption makes human bone $\mathrm{Sr}$ ratios equilibrate toward the seawater value of 0.7092 . As discussed above, the ${ }^{87} \mathrm{Sr} /{ }^{86} \mathrm{Sr}$ ratios of terrestrial sources would be about 0.7086 , inferred from the Sr isotope values of plants in the Yoshigo area and the local geology. Interestingly, mixing these two components resulted in a continuous gradation observed between 0.7086 and 0.7092 , and extensively between 0.7088 and 0.7092 (Fig. 4). The gradation appears to indicate different proportions of dietary dependence on marine foods. Thus, we assumed the local, biologically available Sr isotope ratios to be $0.7086-0.7092$, and that 25 individuals out of 39 are locals. On the other hand 14 individuals whose enamel showed ${ }^{87} \mathrm{Sr} /{ }^{86} \mathrm{Sr}$ ratios of above 0.7092 consumed marine foods and terrestrial foods with higher Sr isotope values. Because high $\mathrm{Sr}$ isotope ratios in enamel $(>0.7092)$ are not likely to be recorded from the Atsumi Peninsula, those individuals would be immigrant members of the Yoshigo population.

There is a clear break in the continuous gradation at 0.7087 , particularly among females (Fig. 4). One male and one female may be immigrants, possibly from inland in the eastern area. However, we did not identify them as immigrants because the lowest values can also be explained by the fully terrestrial food consumption at the Yoshigo site.

In Fig. 4, most of the bone ${ }^{87} \mathrm{Sr} /{ }^{86} \mathrm{Sr}$ values are within the local ${ }^{87} \mathrm{Sr} /{ }^{86} \mathrm{Sr}$ range. Since bone $\mathrm{Sr}$ isotope values are a mixed signature of the diet of individuals and diagenesis, this association enhances the feasibility of setting the local ${ }^{87} \mathrm{Sr} /{ }^{86} \mathrm{Sr}$ range.

In Fig. 5, all measured ${ }^{87} \mathrm{Sr} /{ }^{86} \mathrm{Sr}$ ratios in tooth enamel and bone of each individual are arranged according to each tooth ablation type. Table 3 shows the number and proportion of immigrants, and their classification according to sex, ritual tooth ablation types, and the presence of offerings in burials. These results are significant for testing Harunari's hypothesis (see later discussion).

\section{Discussion}

\subsection{Testing Harunari's (1979) hypothesis}

Application of $\mathrm{Sr}$ isotope analysis to the Yoshigo skeletal remains with definite ritual tooth ablation does not support Harunari's (1979) hypothesis that type 4I individuals are locals and type $2 \mathrm{C}$ individuals are immigrants. According to the criterion of the local ${ }^{87} \mathrm{Sr} /{ }^{86} \mathrm{Sr}$ range of $0.7086-0.7092$, four $(24 \%)$ out of 17 individuals were identified as immigrants among type 4I individuals, and five (56\%) out of nine individuals were identified as immigrants among type $2 \mathrm{C}$ individuals (Fig. 5, Table 3). Not all type 2C individuals were immigrants, however, and type $4 \mathrm{I}$ individuals also include immigrants. Furthermore, one of the two type 0 individuals, who were regarded as unmarried local individuals by Harunari (1979), was an immigrant.

Harunari (1979) further hypothesized that type 4I individuals were more prestigious than type $2 \mathrm{C}$ individuals, and that type $4 \mathrm{I}$ individuals were locals, because type $4 \mathrm{I}$ individuals were more frequently buried with offerings than type $2 \mathrm{C}$ individuals. 
However, both patterns of burial, with and without offerings, include immigrants (Table $3)$. Thus no clear relationship exists between the possession of offerings and immigrants, as Harunari (1979) argued.

Our results clearly show that tooth ablation types do not necessarily match representation of locals and immigrants. We speculate that tooth ablation types represent kin-based descent groups (Kusaka et al., 2008; Yamada, 2008). Stable carbon and nitrogen isotope analysis on the Inariyama skeletal remains revealed that the diet of these subjects was associated with ritual tooth ablation types; i.e., type $4 \mathrm{I}$ individuals consumed terrestrial foods, and type $2 \mathrm{C}$ individuals consumed marine foods (Kusaka et al., 2008). This finding suggests that each food procurement group shared the same tooth ablation type, and we assume that these groups possibly correspond to descent groups. This possibility should be explored in other archaeological or anthropological research.

\subsection{Proportion of immigrants among type $4 \mathrm{I}$ and $2 \mathrm{C}$ individuals}

Type $2 \mathrm{C}$ individuals have appreciably higher ${ }^{87} \mathrm{Sr} /{ }^{86} \mathrm{Sr}$ ratios than type $4 \mathrm{I}$ individuals in enamel (Mann-Whitney test: enamel, $P=0.019$ ). This result suggests that type $2 \mathrm{C}$ individuals generally consumed foods with higher ${ }^{87} \mathrm{Sr} /{ }^{86} \mathrm{Sr}$ ratios at least during their childhood and, further, that type $2 \mathrm{C}$ individuals appear to include more immigrants than type 4I individuals. Four (24\%) out of 17 individuals in type 4I and five (56\%) out of nine individuals in type $2 \mathrm{C}$ were identified as immigrants. Although the number of type $2 \mathrm{C}$ individuals is relatively small, the mobility of these individuals might have been higher than that of 4I individuals. This tendency also applies to type 2C2I and 4I2C individuals: type 2C2I individuals include more immigrants (57\%) than type 4I2C individuals (0\%). Mouri and Oku (1998) investigated cranial nonmetric variants of the Yoshigo people, and presented greater similarities among type 4I crania than among type $2 \mathrm{C}$ crania. Their cranial nonmetric variant study and the present study suggest the same possibility; that is, that type $2 \mathrm{C}$ individuals include more immigrants than type $4 \mathrm{I}$ individuals.

\subsection{Geographical origin of immigrants}

Some clusters can be found among the enamel ${ }^{87} \mathrm{Sr} /{ }^{86} \mathrm{Sr}$ ratios of immigrants. One cluster, between 0.7094 and 0.7097, includes four males and three females (Fig. 4). Another cluster, between 0.7099 and 0.7100 , includes three males. These results indicate several places of origin for the immigrants. We predict that the immigrants with high $\mathrm{Sr}$ isotope values originated from inland sites which are less affected by seawater Sr.

Marked inter-regional contrasts in geographic ${ }^{87} \mathrm{Sr} /{ }^{86} \mathrm{Sr}$ distribution in the study area (Fig. 3A) are particularly advantageous for elucidating the geographical origin of immigrants to the Yoshigo site. Specifically, immigrants identified through this study may have originated in the north area, where the mean ${ }^{87} \mathrm{Sr} /{ }^{86} \mathrm{Sr}$ ratio in plants is significantly high. Indeed, another famous site of the Final Jomon period exists in the north area (at the north of the mouth of the Toyo River; Fig. 2), namely, the Inariyama shell mound, from which about 50 human skeletal remains have been excavated (Kiyono, 1969). Future application of the Sr isotopic technique to the Inariyama skeletal remains will help establish the human interaction between the Yoshigo and Inariyama populations.

There are also several Jomon shell mounds of the Late-Final Jomon period in the 
west area, such as the Kawaji, Hobi, and Ikawazu sites (Fig. 2). Because no clear differences can be discerned in the geology and $\mathrm{Sr}$ isotope ratios of plants in the west area and the Yoshigo area, immigrants from these areas to the Yoshigo population, if any, cannot be identified through $\mathrm{Sr}$ isotope analysis. Thus, the number of immigrants in the Yoshigo site may be the minimum estimate.

\subsection{Mobility of the Yoshigo population}

Our study indicates a high proportion (36\%) of immigrants among the Yoshigo population. Kondo (1994) argued that the heterogeneities of the intra-regional variation of cranial morphology are as large as those of inter-regional variation among the Jomon population from two regions: northern Chiba and the Atsumi Peninsula. Morphological similarity between the regions is also found in tooth metric and nonmetric studies (Matsumura, 1989, 2007). The morphological similarity among the Jomon population could be the result of the high mobility inferred from this study.

Some hunter-gatherer social units have a fluid composition, with individuals and families moving at different times. Thus, the size of each group can be highly variable in annual cycles (Binford, 2001). Various reasons can be suggested for migration among the Jomon people, as described in many ethnographic records of hunter-gatherers (e.g., Kelly, 1995). Hunter-gatherers may migrate as a result of resource depletion, to decrease social stress, or for marriage. Some migrants possibly joined the Yoshigo population as individuals for marriage, and others may have joined as family groups. We cannot elucidate clear reasons from our limited data. Future application of $\mathrm{Sr}$ isotopic techniques at multiple sites could enable a more comprehensive understanding of prehistoric human mobility in Japan.

\section{Conclusions}

(1) Strontium isotope data from human skeletal remains of the Jomon people from the Yoshigo shell mound show that the ${ }^{87} \mathrm{Sr} /{ }^{86} \mathrm{Sr}$ variation in tooth enamel $(0.70925 \pm$ 0.00036 [mean \pm 1 s.d.]) is greater than that in bone $(0.70895 \pm 0.00018)$. Tooth enamel $\mathrm{Sr}$ values from these remains show a continuous gradation between 0.7086 and 0.7092 , suggesting that they belong to locals. This conclusion is supported by the plant $\mathrm{Sr}$ isotope values collected from the surrounding area of the site, and the local geology. Thus, $36 \%$ of the population with enamel values above 0.7092 appear to be immigrants.

(2) Strontium isotope ratios in plants in the north area (= the northern coast of Mikawa Bay) are significantly higher than those around the Yoshigo shell mound, and conform well to tooth enamel ${ }^{87} \mathrm{Sr} /{ }^{86} \mathrm{Sr}$ ratios found among immigrants. The north area is presumably the geographical origin of immigrants.

(3) The most influential hypothesis on the significance of ritual tooth ablation types is that of Harunari (1979), who regarded type 4I individuals as locals and type 2C individuals as immigrants. The present study does not support this hypothesis because both type $2 \mathrm{C}$ and type $4 \mathrm{I}$ individuals include immigrants.

(4) The mean ${ }^{87} \mathrm{Sr} /{ }^{86} \mathrm{Sr}$ ratios in tooth enamel of type $2 \mathrm{C}$ individuals in the Yoshigo population are significantly higher than those of type 4I individuals, which suggests that type $2 \mathrm{C}$ individuals include many immigrants compared with type $4 \mathrm{I}$ individuals. 
Journal of Archaeological Science 36 (2009) 2289-2297

\section{Acknowledgements}

The authors wish to thank M. Nakatsukasa (Kyoto University), N. Ogihara (Keio University), and members of the Laboratory of Physical Anthropology, Kyoto University for their helpful discussions and comments; T. Kobayashi (RIHN), E. Kokado (RIHN), and Y. Yokoo (Doshisha University) for their instruction in the experimental techniques; T. Masuyama (Tahara City, Aichi Prefecture) and the Educational board of Tahara City for offering samples for preliminary experiments; and members of Project D-02 of RIHN for the help they gave with this study. The study was performed as a part of Project D-02, "A New Cultural and Historical Exploration into Human-Nature Relationships in the Japanese Archipelago" at RIHN. Finally, we would like to thank three anonymous reviewers for their insightful comments and positive criticisms on our original manuscript. 


\section{References}

Bentley, R.A., 2006. Strontium isotopes from the earth to the archaeological skeleton: A review. J. Archaeol. Meth. Theor. 13, 135-187.

Bentley, R.A., Price, T.D., Lüning, J., Gronenborn, D., Wahl, J., Fullagar, P.D., 2002. Prehistoric migration in Europe: Strontium isotope analysis of Early Neolithic skeletons. Curr. Anthrop. 43, 799-804.

Bentley, R.A., Pietrusewsky, M., Douglas, M.T., Atkinson, T.C., 2005. Matrilocality during the prehistoric transition to agriculture in Thailand? Antiquity. 79, $865-881$.

Bentley, R.A., Tayles, N., Higham, C., Macpherson, C., Atkinson, T.C., 2007. Shifting gender relations at Khok Phanom Di, Thailand. Curr. Anthrop. 48, 301-314.

Binford, L.R., 2001. Constructing Frames of Reference: An Analytical Method For Archaeological Theory Building Using Hunter-Gatherer and Environmental Data Sets. University of California Press, California.

Blum, J.D., Taliaferro, E.H., Weisse, M.T., Holmes, R.T., 2000. Changes in Sr/Ca, $\mathrm{Ba} / \mathrm{Ca}$ and ${ }^{87} \mathrm{Sr} /{ }^{86} \mathrm{Sr}$ ratios between trophic levels in two forest ecosystems in the northeastern U.S.A. Biogeochemistry. 49, 87-101.

Ezzo, J.A., Johnson, C.M., Price, T.D., 1997. Analytical perspectives on prehistoric migration: A case study from East-Central Arizona. J. Archaeol. Sci. 24, 447-466.

Faure, G., Mensing, T.M., 2005. Isotopes: Principles and Applications, third ed. John Wiley \& Sons, Inc., New Jersey.

Funahashi, K., 2003. A study of the timing of ritual tooth ablation and its meaning as rites of passage in Final Jomon period. Q. Archaeol. Stud. 50, 56-76 (in Japanese, with English abstract).

Haak, W., Brandt, G., Jong, H.N.d., Meyer, C., Ganslmeier, R., Heyd, V., Hawkesworth, C., Pike, A.W.G., Meller, H., Alt, K.W., 2008. Ancient DNA, strontium isotopes, and osteological analyses shed light on social and kinship organization of the Later Stone Age. Proc. natn. Acad. Sci. U.S.A. 105, 18226-18231.

Habu, J., 2004. Ancient Jomon of Japan. Cambridge University Press, Cambridge.

Harunari, H., 1979. Postmarital modes of residence of the Final Jomon period. J. Facul. Low Litera. Okayama Univ. 40, 25-63 (in Japanese).

Harunari, H., 1986. Rules of residence in the Jomon period, based on the analysis of tooth extraction in: Pearson, R.J. (Ed.), Windows on the Japanese Past: Studies in Archaeology and Prehistory. Center for Japanese studies, The University of Michigan, pp. 293-310.

Hasebe, K., 1919. Ritual tooth ablation of the Stone Age people. J. Anthrop. Soc. Tokyo. 34, 385-392 (in Japanese).

Haverkort, C.M., Weber, A., Katzenberg, M.A., Goriunova, O.I., Simonetti, A., Creaser, R.A., 2008. Hunter-gatherer mobility strategies and resource use based on strontium isotope $(87 \mathrm{Sr} / 86 \mathrm{Sr}$ ) analysis: a case study from Middle Holocene Lake Baikal, Siberia. J. Archaeol. Sci. 35, 1265-1280.

Hillson, S., 1996. Dental Anthropology. Cambridge University Press, Cambridge.

Hodell, D.A., Quinn, R.L., Brenner, M., Kamenov, G., 2004. Spatial variation of strontium isotopes $\left({ }^{87} \mathrm{Sr} /{ }^{86} \mathrm{Sr}\right)$ in the Maya region: A tool for tracking ancient human migration. J. Archaeol. Sci. 31, 585-601.

Hoppe, K.A., Koch, P.L., Furutani, T.T., 2003. Assessing the preservation of biogenic 
strontium in fossil bones and tooth enamel. Int. J. Osteoarchaeol. 13, 20-28.

Hughen, K.A., Baillie, M.G.L., Bard, E., Beck, J.W., Bertrand, C.J.H., Blackwell, P.G., Buck, C.E., Burr, G.S., Cutler, K.B., Damon, P.E., Edwards, R.L., Fairbanks, R.G., Friedrich, M., Guilderson, T.P., Kromer, B., McCormac, G., Manning, S., Ramsey, C.B., Reimer, P.J., Reimer, R.W., Remmele, S., Southon, J.R., Stuiver, M., Talamo, S., Taylor, F.W., Plicht, J.v.d., Weyhenmeyer, C.E., 2004. Marine04 marine radiocarbon age calibration, 0-26 cal kyr BP. Radiocarbon. 46, 1059-1086.

Hyodo, F., Tayasu, I., Konat, S., Tondoh, J.E., Lavelle, P., Wada, E., 2008. Gradual enrichment of ${ }^{15} \mathrm{~N}$ with humification of diets in a below-ground food web: relationship between ${ }^{15} \mathrm{~N}$ and diet age determined using ${ }^{14} \mathrm{C}$. Funct. Ecol. 22, $516-522$.

Imamura, K., 1996. Prehistoric Japan: New Perspectives on Insular East Asia. University of Hawaii Press, Honolulu.

Kelly, R.L., 1995. The Foraging Spectrum: Diversity in Hunter-Gatherer Lifeways. Smithsonian Institution Press, Washington, DC.

Kiyono, K., 1969. The Study of Japanese Shell Middens. Iwanami Shoten, Tokyo (in Japanese).

Knudson, K.J., Buikstra, J.E., 2007. Residential mobility and resource use in the Chiribaya polity of southern Peru: Strontium isotope analysis of archaeological tooth enamel and bone. Int. J. Osteoarchaeol. 17, 563-580.

Kondo, O., 1994. The skulls of Ubayama shell-mounds II. An analysis of intra- and inter-regional variation of the Jomon population. Anthrop. Sci. 102, 59-74.

Kusaka, S., Ikarashi, T., Hyodo, F., Yumoto, T., Katayama, K., 2008. Variability in stable isotope ratios in two Late-Final Jomon communities in the Tokai coastal region and its relationship with sex and ritual tooth ablation. Anthrop. Sci. 116, $171-181$.

Makimoto, H., Yamada, N., Mizuno, K., Takada, A., Komazawa, M., Sudo, S., 2004. Geological map of Japan 1:200,000, Toyohashi and Irago Misaki. Geol. Surv. Japan, AIST (in Japanese).

Matsumura, H., 1989. Geographical variation of dental measurements in the Jomon population. J. anthrop. soc. Nippon. 97, 493-512.

Matsumura, H., 2007. Non-metric dental trait variation among local sites and regional groups of the Neolithic Jomon period, Japan. Anthrop. Sci. 115, 25-33.

Montgomery, J., Evans, J.A., Cooper, R.E., 2007. Resolving archaeological populations with Sr-isotope mixing models. Appl. Geochem. 22, 1502-1514.

Mouri, T., Oku, C., 1998. A test of Harunari's hypothesis by nonmetric cranial variants. Q. Archaeol. Stud. 45, 91-101 (in Japamese, with English abstract).

Nakano, T., Morohashi, S., Yasuda, H., Sakai, M., Aizawa, S., Shichi, K., Morisawa, T., Takahashi, M., Sanada, M., Matsuura, Y., Sakai, H., Akama, A., Okada, N., 2006. Determination of seasonal and regional variation in the provenance of dissolved cations in rain in Japan based on $\mathrm{Sr}$ and $\mathrm{Pb}$ isotopes. Atmos. Environ. 40, 7409-7420.

Price, T.D., Burton, J.H., Bentley, R.A., 2002. The characterization of biologically available strontium isotope ratios for the study of prehistoric migration. Archaeometry. 44, 117-135.

Reimer, P.J., Baillie, M.G.L., Bard, E., Bayliss, A., Beck, J.W., Bertrand, C.J.H., Blackwell, P.G., Buck, C.E., Burr, G.S., Cutler, K.B., Damon, P.E., Edwards, 
R.L., Fairbanks, R.G., Friedrich, M., Guilderson, T.P., Hogg, A.G., Hughen, K. A., Kromer, B., McCormac, G., Manning, S., Ramsey, C.B., Reimer, R.W., Remmele, S., Southon, J.R., Stuiver, M., Talamo, S., Taylor, F.W., Plicht, J.v.d., Weyhenmeyer, C.E., 2004. IntCal04 terrestrial radiocarbon age calibration, 0-26 cal kyr BP. Radiocarbon. 46, 1029-1058.

Sillen, A., 1986. Biogenic and diagenetic $\mathrm{Sr} / \mathrm{Ca}$ in Plio-Pleistocene fossils of the Omo Shungura Formation. Paleobiology. 12, 311-323.

Stenhouse, M.J., Baxter, M.S., 1979. The uptake of bomb ${ }^{14} \mathrm{C}$ in humans in: Berkeley, R., Suess, H. (Eds.), Radiocarbon Dating. University of California Press, pp. 324-341.

Stuiver, M., Reimer, P.J., 1993. Extended ${ }^{14} \mathrm{C}$ data base and revised CALIB $3.0{ }^{14} \mathrm{C}$ age calibration program. Radiocarbon. 35, 215-230.

Tafuri, M.A., Bentley, R.A., Manzi, G., di Lernia, S., 2006. Mobility and kinship in the prehistoric Sahara: Strontium isotope analysis of Holocene human skeletons from the Acacus Mts. (southwestern Libya). J. Anthrop. Archaeol. 25, 390-402.

Tanaka, Y., 1998. A reconsideration of the concept of descent in Japanese archaeology. Nihon-Kokogaku. 5, 1-18 (in Japanese).

Trickett, M.A., Budd, P., Montgomery, J., Evans, J., 2003. An assessment of solubility profiling as a decontamination procedure for the ${ }^{87} \mathrm{Sr} /{ }^{86} \mathrm{Sr}$ analysis of archaeological human skeletal tissue. Appl. Geochem. 18, 653-658.

Watanabe, M., 1966. A study of ritual tooth ablation in the Jomon culture. Kodaigaku. 12, 173-201 (in Japanese).

Whipkey, C.E., Capo, R.C., Chadwick, O.A., Stewart, B.W., 2000. The importance of sea spray to the cation budget of a coastal Hawaiian soil: a strontium isotope approach. Chem. Geol. 168, 37-48.

Wright, L.E., 2005. Identifying immigrants to Tikal, Guatemala: Defining local variability in strontium isotope ratios of human tooth enamel. J. Archaeol. Sci. $32,555-566$.

Yamada, Y., 2008. Mortuary practice and society of Jomon period through excavated human skeletal remains. Douseisha, Tokyo (in Japanese).

Yamanouchi, S. 1952. The second trench in: The Shell Mounds of Yoshigo. The Commission for the Protection of Cultural Properties Japan, pp.93-124 (in Japanese, with English abstract).

Yoneda, M., Saso, A., Suzuki, R., Shibata, Y., Morita, M., Suwa, G., Akazawa, T., 2005. Chronology of the Yayoi Skeletal remains from the Kanto district, Japan: A preliminary re-evaluation by radiocarbon dating of postcranial material. Anthrop. Sci. 113, 169-182.

Yoneda, M., Shibata, Y., Tanaka, A., Uehiro, T., Morita, M., Uchida, M., Kobayashi, T., Kobayashi, C., Suzuki, R., Miyamoto, K., Hancock, B., Dibden, C., Edmonds, J. S., 2004. AMS ${ }^{14} \mathrm{C}$ measurement and preparative techniques at NIES-TERRA. Nucl. Instrum. Methods Phys. Res., Sect. B. 223-224, $116-123$. 
Journal of Archaeological Science 36 (2009) 2289-2297

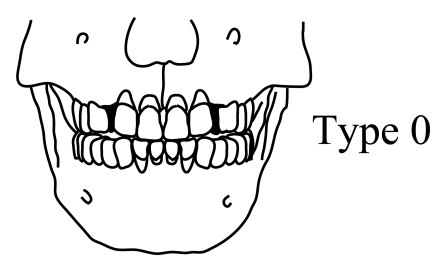

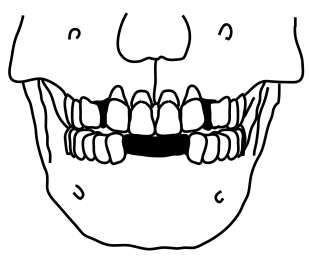

Type 4I

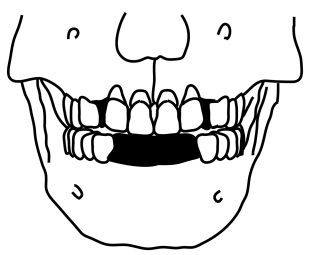

Type 4I2C

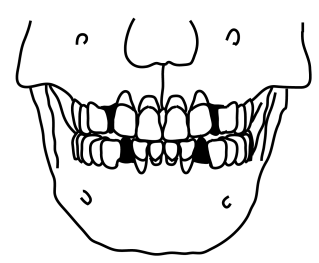

Type $2 \mathrm{C}$

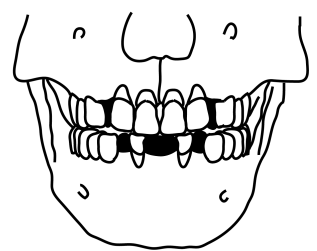

Type 2C2I

Figure 1: Types of ritual tooth ablation based on Harunari (1979). 


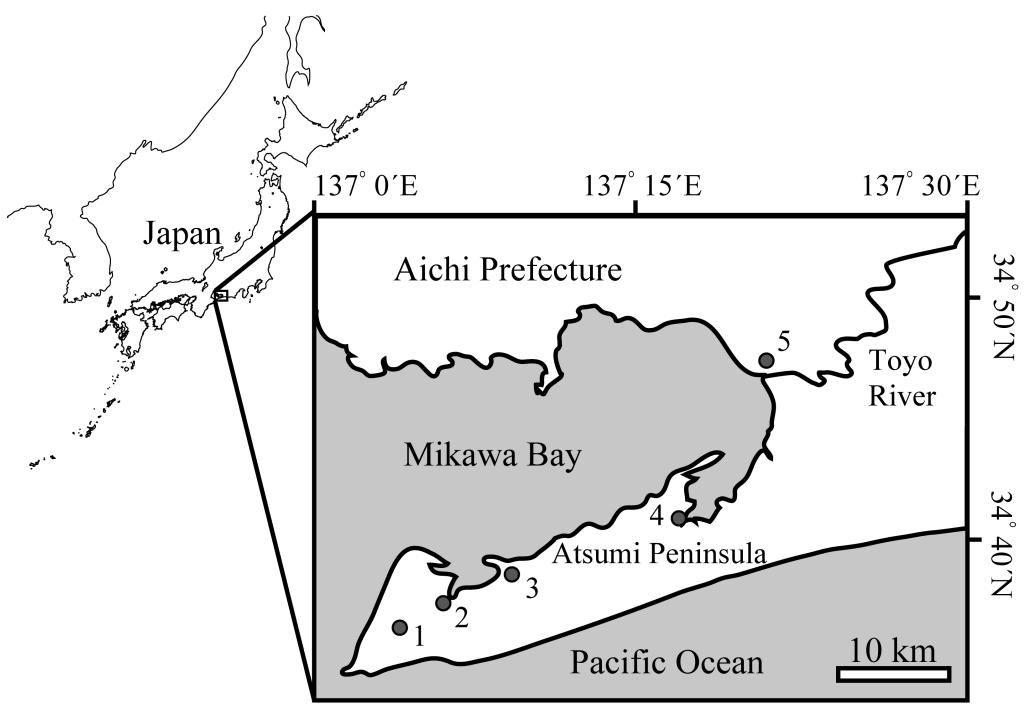

Figure 2: Plan map of study area in Aichi Prefecture, Japan, showing the location of the Yoshigo shell mound in the Late-Final Jomon period and other contemporary shell mounds discussed in the text. Numbered gray circles are locations of the shell mounds: 1, Kawaji; 2, Hobi; 3, Ikawazu; 4, Yoshigo; 5, Inariyama. 
Journal of Archaeological Science 36 (2009) 2289-2297
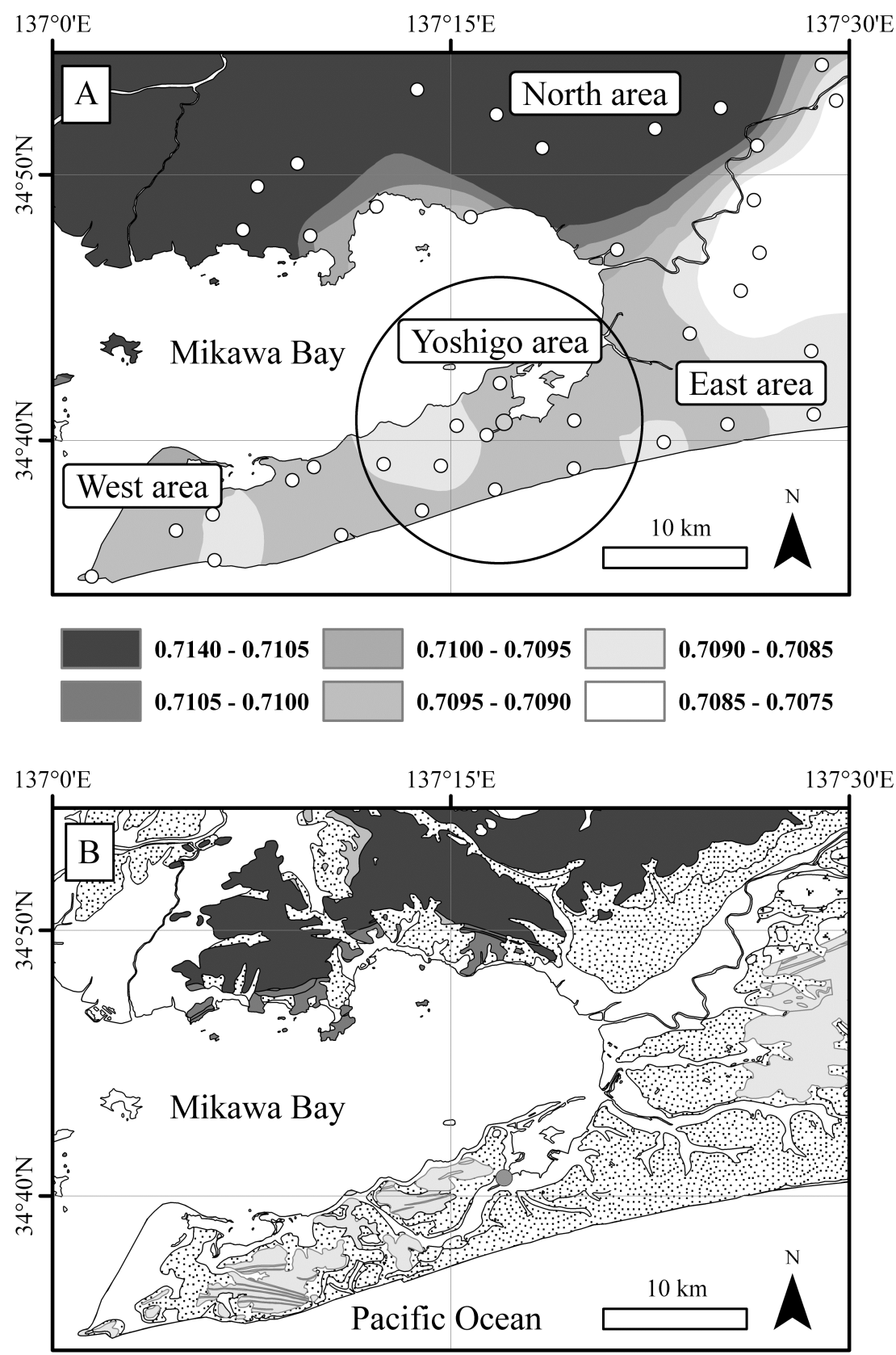

\footnotetext{
Holocene (Gravel, sand and clay)

Pliocene (Gravel, sand and clay)

Miocene (Sandstone, mudstone and conglomerate)
}

Cretaceous (Metamorphic rocks in the Ryoke Belt) Cretaceous (Granitic rocks in the Ryoke Belt)

Paleozoic (Limestone and chert in the Chichibu Belt)

Figure 3: (A) Map of geographic distribution of Sr isotope ratios in plants in study area surrounding Mikawa Bay. Graphic representation is based on ArcGIS (ESRI, Inc.) software through the calculation method of kriging. Open circles are the locations where plant samples were collected. The gray circle is the location of the Yoshigo shell mound. (B) The geological map of the study area was modified from the 1:200,000 geological map "Toyohashi and Irago Misaki" (Makimoto et al., 2004). 
Journal of Archaeological Science 36 (2009) 2289-2297

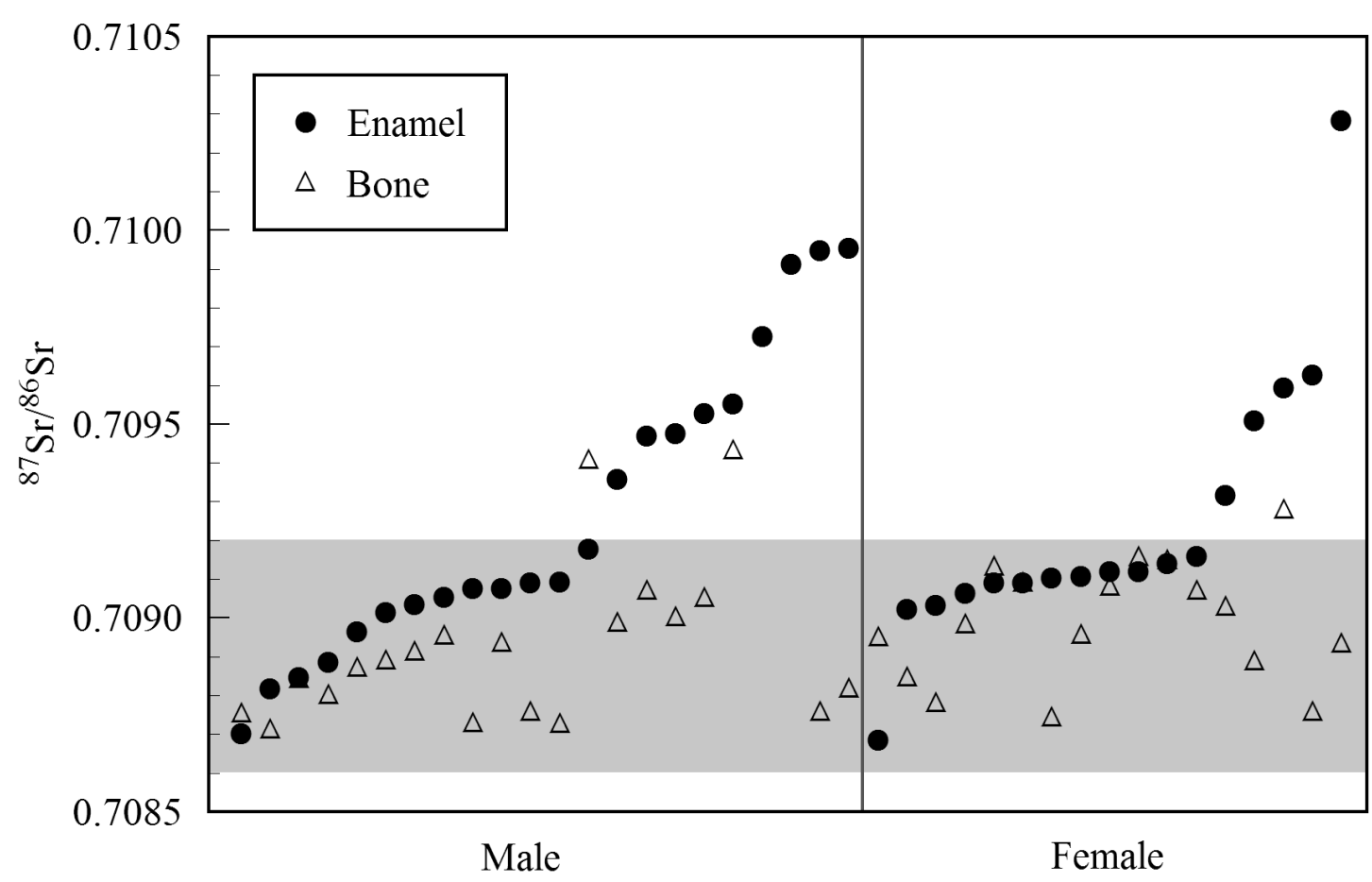

Figure 4: Strontium isotope ratios in human tooth enamel and bone of the Yoshigo skeletal remains. A pair of the ${ }^{87} \mathrm{Sr} /{ }^{86} \mathrm{Sr}$ ratios of tooth enamel and bone on the same transverse axis is generated from the same individual, and these individuals are categorized by sex. The gray horizontal bar indicates the local ${ }^{87} \mathrm{Sr} /{ }^{86} \mathrm{Sr}$ range of $0.7086-0.7092$. 
Journal of Archaeological Science 36 (2009) 2289-2297

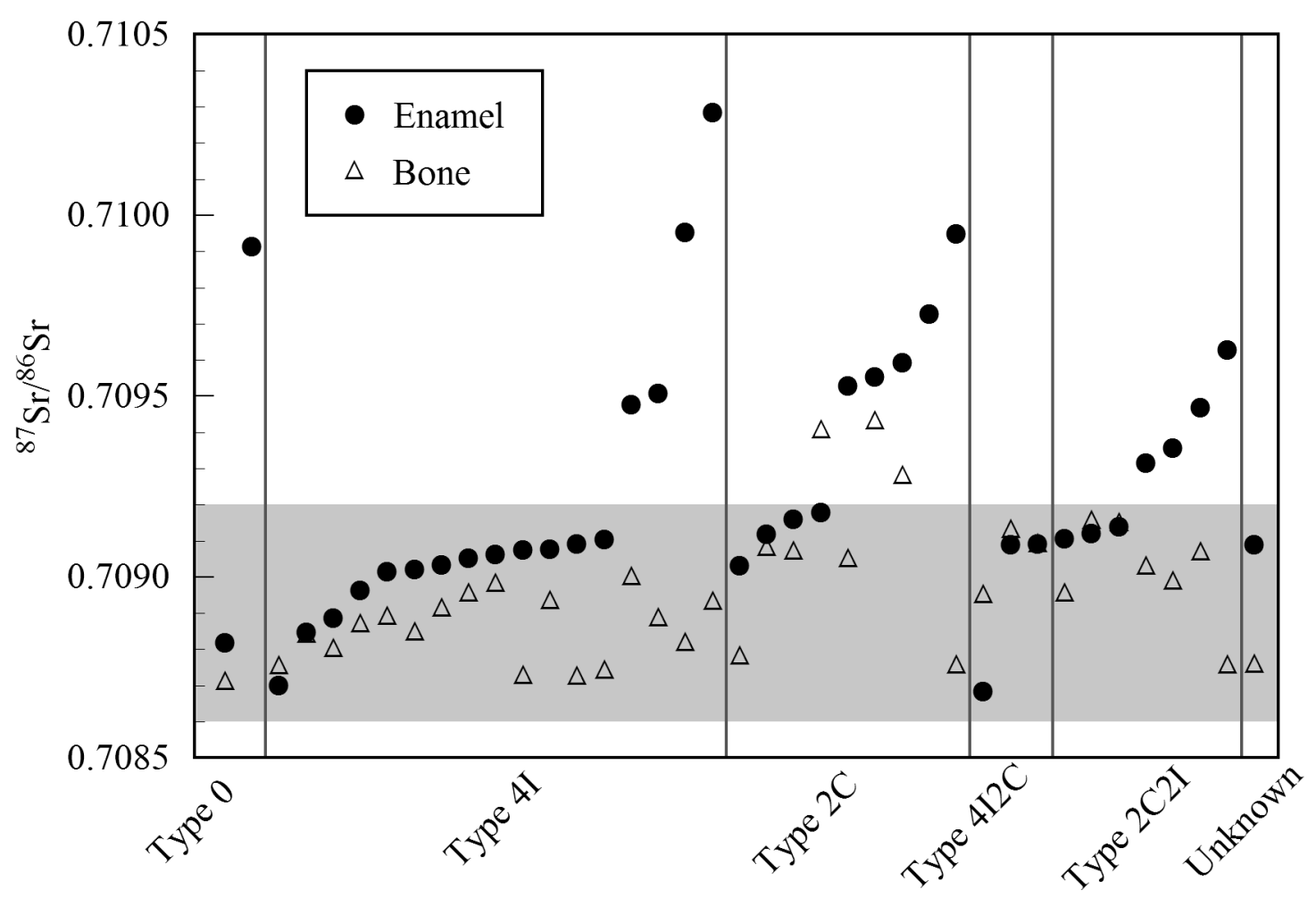

Figure 5: Strontium isotope ratios in human tooth enamel and bone of the Yoshigo skeletal remains categorized by ritual tooth ablation types. 
Journal of Archaeological Science 36 (2009) 2289-2297

Table 1. Cultural history of Jomon period.

\begin{tabular}{lllll}
\hline Period & Uncalibrated BP & General description & Mortuary tradition & Ritual tooth ablation \\
\hline Incipient-Initial Jomon & $13000-6000$ & Pottery, large settlements & Flexed & Absent \\
Early-Middle Jomon & $6000-4000$ & Increasing population, large shell mounds & Flexed, extended & Upper lateral incisors \\
Late-Final Jomon & $4000-2300$ & Decreasing population, ritual artifacts & Flexed, extended, second burial, offerings & Canines, incisors \\
\hline
\end{tabular}


Journal of Archaeological Science 36 (2009) 2289-2297

Table 2. Difference in mean $\mathrm{Sr}$ isotope ratios in plants among four regions in the study area and results of Student's $t$-test (unpaired data with unequal variance).

\begin{tabular}{llll}
\hline & West area & East area & North area \\
\hline Yoshigo area & 0.00030 & -0.00048 & $0.00234^{*}$ \\
& $P=0.8297$ & $P=0.1483$ & $P=0.0009$ \\
West area & & -0.00051 & $0.00231^{*}$ \\
& & $P=0.1156$ & $P=0.0010$ \\
East area & & & $0.00281^{*}$ \\
& & & $P=0.0002$ \\
\hline
\end{tabular}

$* P<0.01$ 
Journal of Archaeological Science 36 (2009) 2289-2297

Table 3. Number and proportion of immigrants in the Yoshigo skeletal remains categorized by selected archaeological characteristics.

\begin{tabular}{llccc} 
Characters & & Total & Locals & Immigrants (\%) \\
& & & & \\
\hline $\begin{array}{l}\text { All samples } \\
\text { Sex }\end{array}$ & 39 & 25 & $14(36)$ \\
& Male & 22 & 13 & $9(41)$ \\
\multirow{4}{*}{ Ritual tooth ablation } & Female & 17 & 12 & $5(29)$ \\
& Type 0 & 2 & 1 & $1(50)$ \\
& Type 4I & 17 & 13 & $4(24)$ \\
& Type 2C & 9 & 4 & $5(56)$ \\
& Type 4I2C & 3 & 3 & $0(0)$ \\
& Type 2C2I & 7 & 3 & $4(57)$ \\
& Unknown & 1 & 1 & $0(0)$ \\
Offerings & & & & \\
& Present & 9 & 4 & $5(56)$ \\
& Absent & 30 & 21 & $9(30)$ \\
\hline
\end{tabular}




\section{Appendix 1. Results of radiocarbon dating.}

Radiocarbon ages of three randomly selected Yoshigo human skeletons were measured by accelerator mass spectrometer at National Institute for Environmental Studies (Yoneda et al., 2004). Extraction of bone collagen and purification of graphite were carried out at RIHN following the methods of Kusaka et al. (2008) and Hyodo et al. (2008), respectively. The results of carbon isotope measurements of the bone collagen have already been described by Kusaka et al. (2008).

In order to properly estimate radiocarbon ages of human skeletons, the marine reservoir effect needs to be calibrated. The percentage of marine food of the human bone collagen (Marine \%) was estimated using a linear mixing of $\delta^{13} \mathrm{C}$ values between $-21.0 \%$ and $-12.5 \%$, which are the representative values for pure terrestrial (C3) and pure marine consumers, respectively (Yoneda et al., 2005). Calibrated ${ }^{14} \mathrm{C}$ ages were calculated from conventional ${ }^{14} \mathrm{C}$ ages by the Calib program version 5.0 (Stuiver and Reimer, 1993). A calibration curve mixing the atmospheric (INTCAL04; Reimer et al., 2004) and the marine datasets (MARINE04; Hughen et al., 2004) should be used for each sample, depending on the estimated percentage of marine carbon in each sample's collagen.

The results are listed in Table A1. New radiocarbon ages of Yoshigo skeletal remains are ca. 3200-2800 cal BP, essentially conforming to previous chronology of the site based on the pottery types (ca. 3500-2300 BP). 
Journal of Archaeological Science 36 (2009) 2289-2297

Table A1. Radiocarbon ages for Yoshigo human skeletal remains.

\begin{tabular}{cccccccc}
\hline Lab. Code & $\begin{array}{c}\text { Sample } \\
\text { No. }\end{array}$ & $\begin{array}{c}\text { Conventional } \\
\text { radiocarbon } \\
\text { age (BP) }\end{array}$ & $\mathrm{C} / \mathrm{N}$ & $\delta^{13} \mathrm{C}$ & $\begin{array}{c}\text { Marine } \\
\%\end{array}$ & $\begin{array}{c}2 \sigma \text { ranges of } \\
\text { calibrated age } \\
\text { (cal BP) }\end{array}$ & $\begin{array}{c}\text { Probability } \\
(\%)\end{array}$ \\
\hline TERRA - & 281 & $2900 \pm 45$ & 3.4 & -19.3 & 20 & $2801-2824$ & 1.5 \\
$080707 b 29$ & & & & & & $2839-3079$ & 98 \\
& & & & & & $3096-3103$ & 0.5 \\
TERRA - & 295 & $2770 \pm 50$ & 3.3 & -16.6 & 52 & $2838-3163$ & 100 \\
$\begin{array}{c}\text { 080707b15 } \\
\text { TERRA }-\end{array}$ & 341 & $3190 \pm 40$ & 3.3 & -13.5 & 88 & $2909-3193$ & 100 \\
$080707 b 30$ & & & & & & & \\
\hline
\end{tabular}


Appendix 2. Characters and ${ }^{87} \mathrm{Sr} /{ }^{86} \mathrm{Sr}$ data of Yoshigo human skeletal remains.

\begin{tabular}{|c|c|c|c|c|c|c|}
\hline $\begin{array}{c}\text { Sample } \\
\text { No. }\end{array}$ & Sex & Age at death & $\begin{array}{l}\text { Tooth } \\
\text { ablation } \\
\text { type }\end{array}$ & Offering $^{a}$ & $\begin{array}{c}{ }^{87} \mathrm{Sr} /{ }^{86} \mathrm{Sr} \text { in } \\
\text { enamel }\end{array}$ & $\begin{array}{l}{ }^{87} \mathrm{Sr} /{ }^{86} \mathrm{Sr} \text { in } \\
\text { bone }\end{array}$ \\
\hline
\end{tabular}

\begin{tabular}{|c|c|c|c|c|c|c|c|}
\hline 273 & male & young adult & $4 \mathrm{I}$ & - & 0.708958 & 0.708868 & local \\
\hline 280 & male & adolescent & $4 \mathrm{I}$ & - & 0.709047 & 0.708951 & local \\
\hline 287 & female & middle adult & $2 \mathrm{C} 2 \mathrm{I}$ & - & 0.709311 & 0.709026 & immigrant \\
\hline 292 & male & young adult & Unknown & - & 0.709085 & 0.708755 & local \\
\hline 302 & female & young adult & $2 \mathrm{C}$ & - & 0.709114 & 0.709078 & local \\
\hline 310 & female & young adult & $2 \mathrm{C} 2 \mathrm{I}$ & - & 0.709135 & 0.709146 & local \\
\hline 316 & male & young adult & $2 \mathrm{C}$ & - & 0.709548 & 0.709429 & immigrant \\
\hline 322 & female & young adult & $4 \mathrm{I} 2 \mathrm{C}$ & - & 0.709086 & 0.709088 & local \\
\hline 333 & male & young adult & $2 \mathrm{C}$ & - & 0.709722 & - & immigrant \\
\hline 335 & female & adolescent & $2 \mathrm{C} 2 \mathrm{I}$ & - & 0.709115 & 0.709153 & local \\
\hline 341 & male & adolescent & 0 & - & 0.709908 & - & immigrant \\
\hline 342 & female & middle adult & $4 \mathrm{I}$ & - & 0.709017 & 0.708844 & local \\
\hline 345 & male & middle adult & $4 \mathrm{I}$ & $\mathrm{H}$ & 0.708696 & 0.708750 & local \\
\hline 349 & male & young adult & $4 \mathrm{I}$ & - & 0.709471 & 0.708998 & immigrant \\
\hline 352 & female & adolescent & $4 \mathrm{I}$ & $\mathrm{H}$ & 0.709058 & 0.708979 & local \\
\hline 357 & female & middle adult & $2 \mathrm{C}$ & - & 0.709154 & 0.709067 & local \\
\hline 363 & male & middle adult & $2 \mathrm{C}$ & $\mathrm{H}$ & 0.709523 & 0.709048 & immigrant \\
\hline 366 & male & middle adult & $4 \mathrm{I}$ & $\mathrm{H}$ & 0.709948 & 0.708815 & immigrant \\
\hline 375 & male & young adult & $4 \mathrm{I}$ & $\mathrm{H}$ & 0.709029 & 0.708910 & local \\
\hline 383 & male & middle adult & $2 \mathrm{C}$ & $\mathrm{H}, \mathrm{E}$ & 0.709943 & 0.708753 & immigrant \\
\hline 386 & male & young adult & $4 \mathrm{I}$ & - & 0.709071 & 0.708932 & local \\
\hline 388 & male & young adult & $4 \mathrm{I}$ & - & 0.709009 & 0.708887 & local \\
\hline 396 & male & young adult & $4 \mathrm{I}$ & - & 0.709070 & 0.708724 & local \\
\hline 404 & female & adolescent & $2 \mathrm{C}$ & - & 0.709027 & 0.708777 & local \\
\hline 408 & female & adult & $4 \mathrm{I}$ & - & 0.710279 & 0.708930 & immigrant \\
\hline 419 & male & young adult & $2 \mathrm{C} 2 \mathrm{I}$ & $\mathrm{H}$ & 0.709352 & 0.708984 & immigrant \\
\hline 435 & male & young adult & $2 \mathrm{C}$ & - & 0.709173 & 0.709404 & local \\
\hline 436 & male & young adult & $2 \mathrm{C} 2 \mathrm{I}$ & - & 0.709464 & 0.709066 & immigrant \\
\hline 460 & female & young adult & $2 \mathrm{C} 2 \mathrm{I}$ & - & 0.709622 & 0.708753 & immigrant \\
\hline 461 & male & middle adult & 0 & - & 0.708813 & 0.708708 & local \\
\hline 481 & male & middle adult & $4 \mathrm{I}$ & - & 0.709087 & 0.708723 & local \\
\hline 488 & female & middle adult & $4 \mathrm{I}$ & - & 0.709503 & 0.708884 & immigrant \\
\hline 500 & female & middle adult & $2 \mathrm{C}$ & E & 0.709588 & 0.709276 & immigrant \\
\hline 509 & male & middle adult & $4 \mathrm{I}$ & $\mathrm{H}$ & 0.708881 & 0.708798 & local \\
\hline 522 & female & young adult & $4 \mathrm{I}$ & - & 0.709098 & 0.708739 & local \\
\hline 523 & female & young adult & $4 \mathrm{I} 2 \mathrm{C}$ & - & 0.709085 & 0.709128 & local \\
\hline 534 & male & middle adult & $4 \mathrm{I}$ & - & 0.708842 & 0.708838 & local \\
\hline 540 & female & middle adult & $4 \mathrm{I} 2 \mathrm{C}$ & - & 0.708679 & 0.708947 & local \\
\hline 541 & female & young adult & $2 \mathrm{C} 2 \mathrm{I}$ & - & 0.709102 & 0.708952 & local \\
\hline
\end{tabular}

${ }^{\mathrm{a}} \mathrm{H}$ - hip accessory; E-earring. 
Journal of Archaeological Science 36 (2009) 2289-2297

Appendix 3. Strontium isotope ratios in plant samples.

\begin{tabular}{|c|c|c|c|c|c|c|}
\hline $\begin{array}{l}\text { Sample } \\
\text { No. }\end{array}$ & Common name & Specific name & ${ }^{87} \mathrm{Sr} /{ }^{86} \mathrm{Sr}$ & Latitude & Longitude & Region $^{\mathrm{a}}$ \\
\hline AP1 & Kakuremino & Dendropanax trifidus & 0.709002 & 34.6703 & 137.2724 & $\mathrm{Y}$ \\
\hline AP2 & Chinese hackberry & Celtis sinensis & 0.709284 & 34.6783 & 137.2834 & $\mathrm{Y}$ \\
\hline AP3 & Inugashi & Neolitsea aciculata & 0.709158 & 34.7027 & 137.2808 & Y \\
\hline AP4 & Japanese mallotus & Mallotus japonicus & 0.708967 & 34.6761 & 137.2537 & Y \\
\hline AP5 & Isunoki & Distylium racemosum & 0.708227 & 34.6510 & 137.2438 & Y \\
\hline AP6 & Horutonoki & Elaeocarpus sylvestris & 0.708857 & 34.6521 & 137.2078 & $\mathrm{Y}$ \\
\hline AP7 & Isunoki & Distylium racemosum & 0.709310 & 34.6502 & 137.1640 & $\mathrm{~W}$ \\
\hline AP8 & Tabunoki & Machilus thunbergii & 0.709099 & 34.6419 & 137.1505 & $\mathrm{~W}$ \\
\hline AP9 & Japanese knotweed & Polygonum cuspidatum & 0.708849 & 34.6205 & 137.1005 & $\mathrm{~W}$ \\
\hline AP10 & Japanese mallotus & Mallotus japonicus & 0.709311 & 34.6103 & 137.0775 & $\mathrm{~W}$ \\
\hline AP11 & Japanese cheesewood & Pittosporum Tobira & 0.709038 & 34.5780 & 137.0246 & W \\
\hline AP12 & Inugashi & Neolitsea aciculata & 0.708882 & 34.5916 & 137.1017 & $\mathrm{~W}$ \\
\hline AP13 & Tabunoki & Machilus thunbergii & 0.709179 & 34.6075 & 137.1813 & $\mathrm{~W}$ \\
\hline AP14 & Round leaf holly & Ilex rotunda & 0.709559 & 34.6229 & 137.2319 & $\mathrm{Y}$ \\
\hline AP15 & Kuroki & Symplocos kuroki & 0.709451 & 34.6360 & 137.2777 & $\mathrm{Y}$ \\
\hline AP16 & Tabunoki & Machilus thunbergii & 0.709147 & 34.6493 & 137.3270 & Y \\
\hline AP17 & Tabunoki & Machilus thunbergii & 0.709004 & 34.6793 & 137.3273 & Y \\
\hline AP18 & Chinese hackberry & Celtis sinensis & 0.708843 & 34.6659 & 137.3837 & $\mathrm{E}$ \\
\hline AP19 & Kakuremino & Dendropanax trifidus & 0.709216 & 34.6770 & 137.4237 & E \\
\hline AP20 & Kakuremino & Dendropanax trifidus & 0.708790 & 34.6833 & 137.4776 & $\mathrm{E}$ \\
\hline AP21 & Japanese mallotus & Mallotus japonicus & 0.709118 & 34.7229 & 137.4761 & $\mathrm{E}$ \\
\hline AP22 & Chinese hackberry & Celtis sinensis & 0.709260 & 34.7339 & 137.3999 & $\mathrm{E}$ \\
\hline AP23 & Chinese hackberry & Celtis sinensis & 0.707303 & 34.7606 & 137.4319 & $\mathrm{E}$ \\
\hline AP24 & Chinese hackberry & Celtis sinensis & 0.708515 & 34.7846 & 137.4437 & $\mathrm{E}$ \\
\hline AP25 & Japanese mallotus & Mallotus japonicus & 0.707000 & 34.8176 & 137.4401 & E \\
\hline AP26 & Chinese hackberry & Celtis sinensis & 0.709845 & 34.8517 & 137.4422 & $\mathrm{E}$ \\
\hline AP27 & Chinese hackberry & Celtis sinensis & 0.708000 & 34.8800 & 137.4917 & $\mathrm{E}$ \\
\hline AP28 & Japanese mallotus & Mallotus japonicus & 0.709260 & 34.9023 & 137.4827 & $\mathrm{~N}$ \\
\hline AP29 & Chinese hackberry & Celtis sinensis & 0.713235 & 34.8753 & 137.4193 & $\mathrm{~N}$ \\
\hline AP30 & Chinese hackberry & Celtis sinensis & 0.712677 & 34.8621 & 137.3781 & $\mathrm{~N}$ \\
\hline AP31 & Japanese mallotus & Mallotus japonicus & 0.713539 & 34.8503 & 137.3074 & $\mathrm{~N}$ \\
\hline AP32 & Chinese hackberry & Celtis sinensis & 0.714209 & 34.8714 & 137.2787 & $\mathrm{~N}$ \\
\hline AP33 & Chinese hackberry & Celtis sinensis & 0.710465 & 34.8869 & 137.2289 & $\mathrm{~N}$ \\
\hline AP34 & Japanese mallotus & Mallotus japonicus & 0.712506 & 34.8406 & 137.1536 & $\mathrm{~N}$ \\
\hline AP35 & Japanese knotweed & Polygonum cuspidatum & 0.710829 & 34.8261 & 137.1286 & $\mathrm{~N}$ \\
\hline AP36 & Japanese mallotus & Mallotus japonicus & 0.713536 & 34.7988 & 137.1196 & $\mathrm{~N}$ \\
\hline AP37 & Tabunoki & Machilus thunbergii & 0.709769 & 34.7952 & 137.1618 & $\mathrm{~N}$ \\
\hline AP38 & Japanese mallotus & Mallotus japonicus & 0.709732 & 34.8136 & 137.2032 & $\mathrm{~N}$ \\
\hline AP39 & Tabunoki & Machilus thunbergii & 0.708805 & 34.8070 & 137.2625 & $\mathrm{~N}$ \\
\hline AP40 & Chinese hackberry & Celtis sinensis & 0.709679 & 34.7865 & 137.3541 & $\mathrm{~N}$ \\
\hline
\end{tabular}

${ }^{\mathrm{a}}$ Y, Yoshigo area; W, west area; E, east area; N, north area. 